\title{
THE CONSUMER POLICY IN THE EU LAW SPOTREBITEL'SKÁ POLITIKA V PRÁVE EÚ
}

\author{
Jarmila LAZÍKOVÁ*
}

\section{Introduction}

The policy of the consumer protection had not been included among the objectives and aims of the European Economic Community. Only the development of the in internal market brought knowledge on the large impact of the effort to create a common market with free movement of goods, services, person and capital. It was not sufficient to move the border searches, custom duties and quantitative restrictions between the member states. It was necessary to harmonise the legal orders of the Member States also in the matters such as contract law, family law, law of succession, to ensure cooperation among the justice bodies of the Member States and to harmonise the policies of the internal issues of the Member States.

The Treaty establishing the European Economic Community did not include the article on the consumer protection. The consumer protection was mentioned in the articles on the economic competition and the common agricultural policy. However, it did not prohibit adoption of the secondary legal rules (i.e. regulations or directions). During the preparation of the Single European Act the secondary legal rules relating to the protection of the consumers' interests were adopted. The Treaty on the European Union was the first legal document of the EU primary law that regulated the consumer protection as one of the policies of the EU. The article 169 of the Treaty on the Functioning of the European Union (hereinafter TFEU) were changing very often; however, the

\section{Abstract (EN)}

Consumer protection is a dominant policy of the EU. Despite this fact, the article 169 of the Treaty on Functioning of the European Union does not enable to adopt the binding legal laws on consumer protection per se. The binding legal laws could be adopted only within the context of other politics and activities on the internal market of the EU. The paper addresses the consumer policy and its status in the EU law by the historical development and legal analysis of the article 169 of the Treaty, secondary law development of consumer protection, jurisprudence, and judicature of the Court of the Justice of the EU.

\section{Keywords (EN)}

consumer, consumer protection, consumer policy, article 169 TFEU meaning of this rule still causes the interpretative difficulties.

\section{Objective and Methodology}

The paper addresses the status of the consumer policy in the EU law from two points of view. First, the legal basis of the law of consumer protection has to be in the EU primary law. The historical development and legal analysis of the article 169 of the TFEU is useful to understand the current status of the consumer policy. Second, the consumer protection is realised by the EU secondary law (i.e. regulations or directives). The development of the secondary law relating to the consumer protection enables to point out the current difficulties in the EU consumer policy. For the purpose of this paper, jurisprudence and judicature of the Court of the Justice of the EU were used. Basic methods of legal science such as legal analysis and comparison were used.

\section{The Consumer Policy from Roma to Lisbon}

The Treaty establishing the European Economic Community did not regulate the consumer protection. There are only two mentions on the consumer. The first mention is connected with the economic competition (articles 85, 86 and 92 (2) TEEC, nowadays articles 101, 102 and 107 TFEU). The second one is connected with the common agricultural policy

\section{Abstrakt (SK)}

Ochrana spotrebitela je jednou z dominantých politík EÚ. Napriek tejto skutočnosti, článok 169 Zmluvy o fungovaní Európskej únie neumožňuje prijat' samostatné záväzné právne predpisy na ochranu spotrebitela. Záväzné právne predpisy môžu byt' prijaté len v kontexte iných politík a činností na vnútornom trhu EÚ. Príspevok sa zameriava na spotrebitel'skú politiku a jej postavenie v práve EÚ, sledovanú prostredníctvom historického vývoja, prostredníctvom právnej analýzy článku 169 Zmluvy a tiež prostredníctvom analýzy vývoja sekundárnej legislatívy ochrany spotrebitela, a judikatúry Súdneho dvora EÚ.

\section{Klưčové slová (SK)}

spotrebitel, ochrana spotrebitela, spotrebitel'ská politika, článok 169 Zmluvy o fungovaní EÚ

* Pan-European University Bratislava, Slovakia 
(articles 39 and 40 TEEC). The European Single Act (1987) entitled the European institutions to adopt a legal regulation relating to the consumer protection. According to the article 18 of the Single European Act (nowadays, article 114 TFEU), the European Commission, in its proposals envisaged in paragraph 1 concerning health, safety, environmental protection and consumer protection, will take as a base a high level of protection. However, the consumer protection was not still included to the single policies of the EEC and the "consumer" was not clearly defined by the legal definition.

The single policy of the consumer protection was established by the Treaty on the European Union (1993). The new article 129a of the Treaty establishing the European Community (TEC) included the consumer protection to the single policies of the EU. This new policy should ensure the health protection, safety, economic interests and providing of information to consumers. The article 129a of the TEC:

1. The Community shall contribute to the attainment of a high level of consumer protection through:

(a) measures adopted pursuant to Article 100a in the context of the completion of the internal market;

(b) specific action which supports and supplements the policy pursued by the Member States to protect the health, safety and economic interests of consumers and to provide adequate information to consumers.

2. The Council, acting in accordance with the procedure referred to in Article 189b and after consulting the Economic and Social Committee, shall adopt the specific action referred to in paragraph 1(b).

3. Action adopted pursuant to paragraph 2 shall not prevent any Member State from maintaining or introducing more stringent protective measures. Such measures must be compatible with this Treaty. The Commission shall be notified of them.

The European Commission had still maintained its duty to take as a base for internal market a high level of consumer protection in article 100a of the TEC. On the other hand, the wording of the article 129a of the TEC resulted in the preference of the Member States' activities; the activities of the Community are only subsidiary function ${ }^{(1)}$. The Jurisprudence is not united in the meaning of these words. The only common statement is that these words are very vague ${ }^{(2)}{ }^{(3)}$.

The European Court of Justice has not provided the legal interpretation of the concept "support and supplement" (article 129a (1b) TEC). The Court provided only the fact that the scope of the article 129a of the TFEU is limited. On the one hand, it provides that the Community is under a duty to contribute to the attainment of a high level of consumer protection. On the other hand, it creates Community competence with a view to specific action relating to consumer protection policy apart from measures taken in connection

(1) Gutman, K. (2014) The Constitutional Foundations of European Contract Law: A comparative Analysis. Oxford: Oxford University Press, 2014. 560 s. ISBN 9780191025471.

(2) Twigg-Flesner, Ch. (2012) A cross-border only regulation for consumer transaction in the EU: A fresh Approach to EU Consumer Law. New York: Springer, 2012. 90 s. ISBN 9781461420477.

(3) Micklitz, H.W. et al. (2010) Consumer Law: Ius Commune Casebooks for a Common Law of Europe. Oxford: Hart Publishing, 2010. 688 s. ISBN 978-1841137490. with the internal market (C-192/94, 19). General Advocate Lenz introduced in his opinion that the article 129a (1) contains an additional innovation inasmuch as it as sets out for the first time competence on the part of the Community to take specific action in the field of consumer protection policy outside the ambit of measures relating to the internal market. (...) This view is also supported by the reinforcement of protection clause contained in Article 129a (3), which leave certain powers to the Member States. Furthermore, the position of Article 129a within the scheme of the Treaty at the end of the part relating to Community policies and the words specific action (rather than measures) tend to suggest that Community activities in this area are not binding (Opinion of Advocate General Lenz 7 December 1995, 32). According to this opinion, the legal binding laws cannot be adopted under the rule 129a (1b). However, there is a contradiction with the connection of the article 129a (2), which enables to adopt legal binding laws by the ordinary legislative procedure in consumer protection regulated in the article 129a (1b).

There results from the wording of the article 129a that the consumer policy is a cross-sectional policy, i.e. the consumer policy creates the objectives together with the objectives of the internal market (article 129a (1b) of the TEC) but it does not create objectives per se. The European Court of justice confirmed this conclusion by its judgement Germany v. European Parliament and Council (C-233/94, 48): "In that regard it suffices to point out that, although consumer protection is one of the objectives of the Community, it is clearly not the sole objective. As has already been stated, the Directive aims to promote the right of establishment and the freedom to provide services in the banking sector. Admittedly, there must be a high level of consumer protection concomitantly with those freedoms; however, no provision of the Treaty obliges the Community legislature to adopt the highest level of protection which can be found in a particular Member State. The reduction in the level of protection which may thereby result in certain cases through the application of the second subparagraph of Article 4(1) of the Directive does not call into question the general result which the Directive seeks to achieve, namely a considerable improvement in the protection of depositors within the Community."

The Amsterdam Treaty renumbered the article 129a of the TEC. From the date of entering the Amsterdam Treaty into force, it is the article 153 of the TEC. The Amsterdam Treaty inserted the consumer rights included in the Preliminary Programme of the EEC for consumer protection and information policy (1975), which had been missing in the article 129a of the TEC. All these consumer rights were set apart in the first subparagraph of the article 153. It caused that the rights should be considered when adopting the legal regulations not only by the article 153 (3b) but also by the article 153 (3a) for the creation of the internal market. The wording of the article 153 after the Amsterdam Treaty:

1. In order to promote the interests of consumers and to ensure a high level of consumer protection, the Community shall contribute to protecting the health, safety and economic interests of consumers, as well as to promoting their right to information, education and to organise themselves in order to safeguard their interests.

2. Consumer protection requirements shall be taken into ac- 
count in defining and implementing other Community policies and activities.

3. The Community shall contribute to the attainment of the objectives referred to in paragraph 1 through:

(a) measures adopted pursuant to Article 95 in the context of the completion of the internal market;

(b) measures which support, supplement and monitor the policy pursued by the Member States.

4. The Council, acting in accordance with the procedure referred to in Article 251 and after consulting the Economic and Social Committee, shall adopt the measures referred to in paragraph 3(b).

5. Measures adopted pursuant to paragraph 4 shall not prevent any Member State from maintaining or introducing more stringent protective measures. Such measures must be compatible with this Treaty. The Commission shall be notified of them.

The second change is a new sub-article 2 that put a duty to all European policy makers to take into account consumer protection requirements in defining and implementing other Community policies and activities. On the one hand, the rule confirmed a cross-sectional character of the consumer policy ${ }^{(4)}$. On the other hand, there was a question if the consumer protection is a single policy enabling to adopt the legal binding laws per se or there needs to be maintained the context of the consumer protection with the other policies and activities of the EU.

The third change of the Amsterdam Treaty consists in a tool that support, supplement and monitor the policy pursued by the Member States (article 153 (3b) of the TEC). By wording of article 129 a the Community had been able to adopt specific actions. By wording of the article 153 the Community was able to adopt measures. This change unified the terminology used in the article 153 (3a) and 153 (3b). This change supports the conclusion that the legal binding laws can be adopted also by the article 153 (3b) of the TEC.

However, these changes did not explain the meaning of the words support, supplement and monitor the policy. The addition of the word monitor brought no more certainty in the article 153 (3b). There was still question what activities of the Community meet the requirements for supporting, supplementing and monitoring of the policy.

The last two sub-articles were not changed by wording and minimum harmonisation standard was confirmed. The minimum harmonisation standard means that the European Union establishes only minimum standard of legal protection and the Member States are entitled to adopt stricter legal rules, of course not contra legem ${ }^{(5)}$.

The last change of the article on consumer protection in the primary law was brought by the Lisbon Treaty. The Lisbon Treaty includes the consumer protection in the share competences between the Union and the Member States (article 4 (2) of the TFEU). The Lisbon Treaty renumbered the

(4) Bourgoignie, T. (1998) European Community consumer law and policy: from Rome to Amsterdam. In: Consumer Law Journal, 1998, s. 443-462.

(5) Ramsay, I. (2012) Consumer Law and Policy: Text and Materials on Regulating Consumer Markets. Portland: Hart Publishing, 2012. 710 s. ISBN 9781849462624 articles again; the article 129a of the TEC, later article 153 of the TEC after the Amsterdam Treaty, is numbered as article 169 of the TFEU after the Lisbon Treaty. The wording of the article 169 of the TFEU is follows:

1. In order to promote the interests of consumers and to ensure a high level of consumer protection, the Union shall contribute to protecting the health, safety and economic interests of consumers, as well as to promoting their right to information, education and to organise themselves in order to safeguard their interests.

2. The Union shall contribute to the attainment of the objectives referred to in paragraph 1 through:

(a) measures adopted pursuant to Article 114 in the context of the completion of the internal market;

(b) measures which support, supplement and monitor the policy pursued by the Member States.

3. The European Parliament and the Council, acting in accordance with the ordinary legislative procedure and after consulting the Economic and Social Committee, shall adopt the measures referred to in paragraph $2(b)$.

4. Measures adopted pursuant to paragraph 3 shall not prevent any Member State from maintaining or introducing more stringent protective measures. Such measures must be compatible with the Treaties. The Commission shall be notified of them.

The wording of the article 169 of the TFEU indicates its addressing to the EU institutions which have a duty to ensure a high level of consumer protection. Therefore, the article does not have usually a direct effect ${ }^{(6)}$. The European Court of the Justice confirmed this opinion in the case El Corte Inglés v. Riverro (C-192/94, 20-23) relating to the omission of the transposition of a directive. The Court states that a consumer is not entitled to base on the directive itself a right of action against a lender who is a private person following in the supply of goods or provision of services and assert that right before a national court. It is a true that there is a horizontal direct effect but the Court does not distinguish between the horizontal and vertical direct effect in the primary law ${ }^{(7)}$.

The sub-article 153 (2) of TEC on consumer protection requirements that shall be taken into account in defining and implementing other Community policies and activities is excluded from the article 169 of the TFEU. Nowadays, this rule is included among the provisions having general application in the article 12 of the TFEU. The change confirms the opinion of jurisprudence about the status of consumer policy that the rules on the consumer protection. It should be taken into account only with the implementation of other policies and activities of the EU and the constitutional entitlement of the European lawmaker for harmonisation of the consumer law in general is not given ${ }^{(8)}$. The new placement of this rule in the article 12 of the TFEU proves that the consumer protection is "a matter which is not a consistent and complex

(6) Jagielska, M., Jagielski, M. (2012) Are consumer rights human rights? In: Devenney, J., Kenn, M. 2012. European Consumer Protection: Theory and Practice. Cambridge: Cambridge University Press, 2012. s. 336-353 ISBN 9781107013018.

(7) Bobek, M. et al. (2011) Vnitrostátní aplikace práva Evropské unie. Praha: C. H. Beck, 2011. 606 s. ISBN 9788074003776.

(8) Weatherill, S. (2013) EU Consumer Law and Policy. Cheltenham: Edward Elgar Publishing Limited, 2013. 352 s. ISBN 9780857936981 . 
law"(9) but shall be taken into account only together with other matters relating to the consumer protection as well; e.g. health protection, environmental protection, safety, etc. ${ }^{(10)}$

By the wording of the article 169 (2a) of the TFEU, it cannot be a self-base for adopting of legal binding rules (e.g. directives or regulations). Its role consists in development of the internal market together with the article 114 of the TFEU by the harmonisation legal binding rules. On the other hand, the article 114 of the TFEU can be a self-base for the adopting of the legal binding rules without article 169 of the TFEU in matters of consumer protection as well (e.g. C-58/08). It seems the article 169 (2a) of the TFEU has the only formal function.

The article 169 (2b) of the TFEU is still problematic in its interpretation. From the wording of the articles 169 (2b) and 169 (3) of the TFEU is clear only the fact that the measures can be adopted by the ordinary legislative procedure; i.e. the legal binding acts for consumer protection can be adopted. From the wording of the articles 169 (2b) and 169 (4) of the TFEU is clear that the European lawmaker has a duty to create or leave an area for lawmakers of the Member States to adopt or to maintain stricter national legal rules ${ }^{(11)}$.

The interpretation of the article 169 (2b) of the TFEU put a question what do the words support, supplement and monitor mean. By the wording of the article 169 (2b) of the TFEU, the article has only function to support, supplement or monitor beside the legislative activities of Member States in consumer protection. A contrario, its role is only to support, supplement or monitor their policies in consumer protection, but not to harmonise or to change their legal rules. The uncertainty of these words causes that the article 169 (2b) of the TFEU has been not very often used as a legal base for EU secondary legislation. There are only few exemptions, e.g. Directive 98/6/EC of the European Parliament and of the Council of 16 February 1998 on consumer protection in the indication of the prices of products offered to consumers and Regulation (EU) No. 254/2014 of the European Parliament and of the Council of 26 February 2014 on a multiannual consumer programme for the years 2014-20 and repealing Decision No 1926/2006/EC. Despite the fact that the regulation (EC) No 2006/2004 of the European Parliament and of the Council of 27 October 2004 on cooperation between national authorities responsible for the enforcement of consumer protection laws (the Regulation on consumer protection cooperation) has already included the character of the supporting, supplementing and monitoring competences in its name, the article 114 of the TFEU became the legal base for the adoption of this regulation without the article 169 (2b) of the TFEU. We can conclude that the article 169 of the TFEU represents the consumer policy as one of the single policies of the EU, but this article is not a self-base for adop-

(9) Procházka, R. - Čorba, J. (2007) Právo Európskej únie. Bratislava: Eurokódex, 2007. 584 s. ISBN 978-80-88931-62-1.

(10) Gutman, K. (2014) The Constitutional Foundations of European Contract Law: A comparative Analysis. Oxford: Oxford University Press, 2014. 560 s. ISBN 9780191025471

(11) Twigg-Flesner, Ch. (2012) A cross-border only regulation for consumer transaction in the EU: A fresh Approach to EU Consumer Law. New York: Springer, 2012. 90 s. ISBN 9781461420477. tion of EU secondary law (i.e. regulations or directives) in the consumer protection matters per se.

\section{The consumer protection in the EU secondary law}

The cross-sectional character of the consumer policy enabled to adopt the EU secondary legislation briefly after the establishment of the European Community because the legal base for adoption of the secondary legislation was taken from other policies of the European Community, i.e. safety (Council Directive 69/493/EEC; Council Directive $87 / 357 /$ EEC), labelling including food labelling (Directive 94/11/EC, Directive 98/6/EC, Directive 98/83/EC, Directive 2002/46/EC), advertisement (Directive 2003/33/EC, Directive 2006/114/EC). There were two reasons for these activities: (1) the fear of the foreign legislation argued consumer out of the cross-border buying; (2) the consumers' mistrust of the adequate legal protection when buying goods and services in abroad $^{(12)}$.

During the preparation of the European Single Act, there are the first efforts to protect the consumers by legislative of the private law. There were adopted more directives, e.g. Council Directive 85/374/EEC of 25 July 1985 on the approximation of the laws, regulations and administrative provisions of the Member States concerning liability for defective products; Council Directive 85/577/EEC of 20 December 1985 to protect the consumer in respect of contracts negotiated away from business premises; or Council Directive 87/102/EEC of 22 December 1986 for the approximation of the laws, regulations and administrative provisions of the Member States concerning consumer credit.

Later, there were adopted also the directives that are not related only selected matters as the above mentioned ones but regulated the complex relations between consumers and businessmen (e.g. Council Directive 93/13/EEC of 5 April 1993 on unfair terms in consumer contracts; Directive 2005/29/EC of the European Parliament and of the Council of 11 May 2005 concerning unfair business-to-consumer commercial practices in the internal market).

Nowadays, the new matter in consumer protection is regarded. It is a civil proceeding (e.g. Directive 2009/22/EC of the European Parliament and of the Council of 23 April 2009 on injunctions for the protection of consumers' interests; regulation (EC) No 861/2009 of the European Parliament and of the Council of 11 July 2007 establishing a European Small Claims Procedure; Directive 2008/52 of the European Parliament and of the Council of 21 May 2008 on certain aspects of mediation in civil and commercial matters; Directive 2013/11/EU of the European Parliament and of the Council of 21 May 2013 on alternative dispute resolution for consumer disputes and amending Regulation (EC) No 2006/2004 and Directive 2009/22/EC; regulation (EU) No 524/2013 of the European Parliament and of the Council

(12) Schurr, F. A. (2007) The relevance of the Euroepan Consumer Protection Law for the Development of the European Contract Law. In: Victoria University of Wellington Law Review, 2007, roč. 38, č. 1, s. 131 - 144 ISSN 1171-042X. 
of 21 May 2013 on online dispute resolution for consumer disputes and amending Regulation (EC) No 2006/2004 and Directive 2009/22/EC).

According to the initiatives of the European Commission published in the Green Paper on the Review of the Consumer Acquis (2008), the European Commission prepared the proposal of a new directive. The proposal was adopted as Directive 2011/83/EU of the European Parliament and of the Council of 25 October 2011on consumer rights, amending Council Directive 93/13/EEC and Directive 1999/44/EC of the European Parliament and of the Council and repealing Council Directive 85/577/EEC and Directive 97/7/EC of the European Parliament and of the Council. Other initiative of the European Commission is addressed to the proposal of a new regulation on a Common European Sales Law. According to this proposal, the new regulation should be only a voluntary tool; by the words of this proposal: "The Common European Sales Law will be a second contract law regime within the national law of each Member State" (Proposal for a regulation of the European Parliament and of the Council on a Common European Sales Law, p. 6).

Nowadays, there are three contract law regimes in the EU Member States. The first one is the regime of the International Convention on Contracts for the International Sale of Goods. The second one is the regime regulated by the Roma Convention I. which was transformed into the regulation (EC) No 593/2008 of the European Parliament and of the Council of 17 June 2008 on the law applicable to contractual obligations (Rome I). The third one is represented by the national legal orders of the Member States on contract law (i.e. 28 various national contract law regimes). However, the new proposals of the regulation will be a fourth contract law regime in the Member States actually13 ${ }^{(13)}$.

The risk of the new tool for sales law consists in the fact that the proposals will not regulate all matters of the sales law but will use a conflict rule for application of a national legal order of a Member State. The fear of this risk is confirmed by the proposal: "As a result, the need for traders to find out about the national laws of other Member States would be limited to only some, much less important, matters which are not covered by the Common European Sales Law" (Proposal for a regulation of the European Parliament and of the Council on a Common European Sales Law, p. 4). The fear of this legal regulation consists in the bad skills with the regulations on the European business companies that are not very often in the internal market of the EU because of the needs to apply European and national legislative as well.

The directive has become a basic legal tool for protection of consumer rights. But a directive needs to be implemented into the national legal orders of the Member States. The Member States have a duty to find a measures and methods how to receive the objectives stipulated by directives. Each Member State can stipulate its own measures and methods how to protect the consumer rights. Moreover, the minimum level of harmonisation regulated by the article 169 (4) of the

(13) Schurr, F. A. (2007) The relevance of the Euroepan Consumer Protection Law for the Development of the European Contract Law. In: Victoria University of Wellington Law Review, 2007, roč. 38, č. 1, s. 131 - 144 ISSN 1171-042X.
TFEU enables to adopt the stricter legal regulations in the national legal orders of the Member States. The result is the existence of 28 various legal regimes of the consumer protection. The proof of the undesirable fact is the Green Report of the Commission on revision of the consumer acquis that analyses the implementation of eight selected consumer directives into the national legal orders of the Member States and identification of many discrepancies in the consumer protection, especially in the matters after the harmonisation. Moreover, there are other problems of the consumer aquis, such as incoherency, ambiguity of consumer aquis and linguistic problems relating to the 24 official languages of the EU. The consumer acquis does not distinguish the national and cross-border legal relationships between consumers and businessmen. It has influenced the core of the national legal regulations of the Member States.

Nowadays, there are many issues that the European policy makers need to answer. The first question is: What tool should be used in further harmonisation process: directives or regulations because the revision of the consumer acquis has proven the disadvantages of directives as the harmonisation tools. Harmonisation through regulations can be most appropriate when regulating new sectors from scratch and easier when the areas concerned allow for limited interaction between EU rules and national systems. In other instances, where upfront harmonisation is not the solution, it is worthwhile exploring the idea of a new regime, an EU framework alternative to but not replacing national rules ${ }^{(14)}$. The second question is if the harmonisation process should relate only to the cross-border legal relations or to national and crossborder legal relations as well. The third question is if the harmonisation process should regulate legal relations B2B (business to business) and B2C (business to consumer) separately or together. On the one hand the EU law tries to bring the harmonisation of the legal relations in the EU Member States in consumer matters, on the other hand the effects of this effort is a factionalism of the legal relations between $\mathrm{B} 2 \mathrm{~B}$ and B2C. It is a very similar situation to the Slovak one where the contract law is regulated by two various codes, the Civil Code regulating the legal relations in general and the Commercial Code regulating the legal relations among the businessmen. The Slovak Republic has the experience in the ineligible consequences with using of two different codes for a legal matter.

\section{Conclusion}

The consumer protection is one of the EU key priorities; however the consumer policy is not a single policy but it has a cross-sectional character. By the article 12 of the TFEU, consumer protection requirements shall be taken into account in defining and implementing other Community policies and activities. The consumer protection is realised by the EU secondary laws (e.g. directives and regulations) that relating vari-

(14) Monti, M. (2010) Nová stratégia pre jednotný trh v službách európskeho hospodárstva a európskej spoločnosti. [online]. [cit. 2015.08.08] Dostupné na internete: <http://ec.europa. eu/internal market/strategy/docs/monti report final_10_05_2010_sk.pdf>. 
ous matters of private or public law. Their legal base is the article 114 of the TFEU alone or together with the article 169 of the TFEU. The article 169 of the TFEU is a self-base for adoption of EU secondary law only rare. The article 169 (2b) of the TFEU is a suitable legal-base for EU secondary laws but the wording of this article is not without doubts. The word monitor, supplement and support were not interpreted by the European Court of Justice. We consider this rule as a suitable legal base for EU secondary law including the law establishing the new EU legal regime but this rule does not allow an adoption of law, which should replace the national regimes of the Members States because it could not be consider as monitor, support or supplement of the activities of the Member States.

The EU secondary law in consumer protection is quite large; however the harmonisation process is not developed by the desirable way. The revision of the consumer acquis has brought information that the harmonisation process did not fulfil its role; therefore, the new tools and method should be considered. However, the factionalism of legal relations B2B and B2C will provide only more complicated legislation and the consumer protection should be consist in the legal rules that are the most intelligible to consumers.

\section{References}

1. Bobek, M. et al. (2011) Vnitrostátní aplikace práva Evropské unie. Praha: C. H. Beck, 2011. 606 s. ISBN 9788074003776.

2. Bourgoignie, T. (1998) European Community consumer law and policy: from Rome to Amsterdam. In: Consumer Law Journal, 1998, s. 443-462.

3. Gutman, K. (2014) The Constitutional Foundations of European Contract Law: A comparative Analysis. Oxford: Oxford University Press, 2014. 560 s. ISBN 9780191025471.

4. Jagielska, M., Jagielski, M. (2012) Are consumer rights human rights? In: Devenney, J., Kenn, M. 2012. European Consumer
Protection: Theory and Practice. Cambridge: Cambridge University Press, 2012. s. 336-353 ISBN 9781107013018.

5. Micklitz, H. W. et al. (2010) Consumer Law: Ius Commune Casebooks for a Common Law of Europe. Oxford: Hart Publishing, 2010. 688 s. ISBN $978-1841137490$.

6. Monti, M. (2010) Nová stratégia pre jednotný trh v službách európskeho hospodárstva a európskej spoločnosti. [online]. [cit. 2015.08.08] Dostupné na internete: <http://ec.europa.eu/internal_market/strategy/docs/monti_report_final_10_05_2010_ sk.pdf>.

7. Procházka, R. - Čorba, J. (2007) Právo Európskej únie. Bratislava: Eurokódex, 2007. 584 s. ISBN 978-80-88931-62-1.

8. Ramsay, I. (2012) Consumer Law and Policy: Text and Materials on Regulating Consumer Markets. Portland: Hart Publishing, 2012. 710 s. ISBN 9781849462624.

9. Siman, M. - Slaštan, M. (2012) Právo Európskej únie. Bratislava: Euroiuris, 2012. 1232 s. ISBN 978-80-89406-12-8.

10. Siman, M. - Slaštan, M. (2012) Súdny systém Európskej únie. Bratislava: Euroiuris, 2012. 786 s. ISBN 978-80-89406-07-4.

11. Schurr, F. A. (2007) The relevance of the Euroepan Consumer Protection Law for the Development of the European Contract Law. In: Victoria University of Wellington Law Review, 2007, roč. 38, č. 1, s. 131 - 144 ISSN 1171-042X.

12. Twigg-Flesner, Ch. (2012) A cross-border only regulation for consumer transaction in the EU: A fresh Approach to EU Consumer Law. New York: Springer, 2012. 90 s. ISBN 9781461420477.

13. Twigg-Flesner, Ch. (2013) The Europeanisation of Contract Law: Current Controversies in Law. New York: Routledge, 2013. 256 s. ISBN 9781138884786.

14. Weatherill, S. (2013) EU Consumer Law and Policy. Cheltenham: Edward Elgar Publishing Limited, 2013. 352 s. ISBN 9780857936981.

\section{Contact address/ Kontaktná adresa}

JUDr. Jarmila Laziková, PhD.

Pan-European University Bratislava,

Tomášikova 150/20, 82102 Bratislava, Slovakia 